\title{
Normkritiska utmaningar i en nyliberal tid: En utblick över ett pedagogiskt landskap
}

\author{
Björkman, Lotta och Bromseth, Janne (red.). 2019. Normkritisk peda- \\ gogik: Perspektiv, utmaningar och möjligheter. Lund: Studentlitteratur. \\ (358 sidor)
}

ANTOLOGIN NORMKRITISK PEDAGOGIK: Perspektiv, utmaningar och möjligheter kan förstås som en uppföljare till antologin Normkritisk pedagogik: Makt, lärande och strategier för förändring, som kom ut 20I0. Bakom den första antologin fanns ett queerpedagogiskt nätverk som myntade det för Sverige unika begreppet "normkritisk pedagogik". Inspirationen kom från den brasilianska pedagogen Paulo Freires kritiska pedagogik, från poststrukturalistiska teorier samt från den amerikanske utbildningsforskaren Kevin Kumashiros pedagogiska teorier. Begreppet fick ett enormt genomslag på en mängd olika arenor - och refereras ofta kort och gott till som "normkritik". I denna antologi, skriven av pedagoger och akademiker som det senaste decenniet på olika sätt arbetat med och utvecklat den normkritiska pedagogiken, är det fortfarande Kumashiros teorier som utgör grunden för en stor del av bidragen. Samtidigt har nya teoretiska influenser tillkommit - inte minst är den feministiska och antirasistiska forskaren Sara Ahmeds arbeten en viktig inspiration för 
flera av bokens bidrag. I den första antologin var det genus- och sexualitetsnormer som stod i fokus. I denna antologi finns en förskjutning mot tidigare mer undanskymda perspektiv, exempelvis normer som rör vithet och funktionalitet.

Båda antologierna är utmärkta tidsdokument och att läsa den senare är att läsa en historieskrivning över det normkritiska begreppets uppkomst, utveckling och förveckling. Redaktörerna till boken menar att den popularisering som följt med begreppets omfattande spridning, bland annat inom myndigheter som Skolverket, har inneburit att det ofta kommit att förstås som en "metod" eller ett "vaccin" mot diskriminering och kränkningar. De påpekar att begreppet har utvecklats under en tid där nyliberala diskurser, med fokus på juridiska regelverk och individens rättigheter, varit starka. Dessa individfokuserade diskurser går dock stick i stäv med den normkritiska pedagogikens rötter i kritisk pedagogik, vars samhällsförändrande ambitioner fokuserar på förtryckande strukturer. I denna bok vill redaktörerna återupprätta de kritiska ambitioner som ibland tycks ha tappats bort längs vägen. De flesta kapitel är skrivna utifrån lärares och utbildares perspektiv på sin yrkespraktik. Samtidigt är den långt ifrån en enkel metodbok. Istället är det processer, möjligheter och utmaningar i en ofta komplex, stressig och ojämlik vardag som står i fokus. Författarna brottas med frågor som rör hur de i sin pedagogiska praktik ska kunna skapa fler demokratiska och inkluderande lärandesituationer. Antologin bidrar både till att bredda och fördjupa de normkritiska perspektiven och till att lyfta fram dilemman och utmaningar med ett normkritiskt pedagogiskt arbete.

Boken består av I3 kapitel och är indelad i fyra huvuddelar: möten med teori, möten med pedagoger, möten med barn eller elever och möten med kollegium. Den spänner över olika utbildningskontexter och har olika fokus: från kroppsmateriella teorier som utmanar idén om läraren som den neutrala kunskapsbäraren till varför normkritiska tankegångar verkar ta stopp när det handlar om vissa former av funktionalitet; från hur normmedvetenhet ibland kan kännas som en olustig begränsning i klassrummet till de känslor av ensamhet som den normkritiskt inspirerade pedagogen kan känna i relation till kollegor. 
Ett genomgående tema i antologin är den kritik som riktats mot att normkritiken, trots sitt fokus på kritiskt tänkande, snarare kan bidra till ett förenklat rätt- och feltänkande, eller som Lotta Björkman uttrycker det, till att fokus hamnar på att vara "normkritiskt korrekt" (2019, I 27). Även Janne Bromseth menar att det bland studenter blir allt vanligare att lägga fokus på ett normmedvetet språk, vilket kan leda till en rädsla att uttala sig i klassrummet. Bromseth refererar till Gunilla Edemo som lyft fram att normkritiken riskerar att bidra till att språket upplevs som ett minfält. Som Jenny Bengtsson och Lena Sotevik påpekar i sitt kapitel kan detta leda till att både lärare och studenter undviker ämnen där terrängen blir mer osäker. Bromseth menar vidare att människor riskerar att bli rangordnade utifrån hur språkligt upplysta de är. Just att normkritiken ibland blivit något av ett upplysningsprojekt, där den upplysta ska lära ut "rätt" kunskaper till de än så länge oupplysta, är något som många bidrag problematiserar. Istället framhålls att lära tillsammans med och att gemensamt utforska makt och normer som idealet.

Elisabet Langmann påpekar i sitt kapitel att ett normkritiskt pedagogiskt arbete innerbär en dubbel rörelse: å ena sidan att värna om och utveckla det som anses värdefullt och eftersträvansvärt i ett samhälle, å andra sidan att kritisera och utmana begränsande föreställningar om vad som är normalt eller önskvärt. Det finns alltså en viss inneboende spänning mellan det normativa och det normkritiska. Langmann gör också en intressant distinktion mellan vad hon kallar direkt och indirekt normkritiskt arbete. Det förra syftar på att med hjälp av normkritiska metoder och reflektionsövningar synliggöra begränsande normer i samhället, medan det senare syftar på att skapa utrymme i undervisningen för att välkomna kunskapskriser när och om de uppstår. Hon menar att båda tjänar sina syften, men att det viktigaste är det indirekta normkritiska arbetet, där den pedagogiska lyhördheten och omdömesförmågan står i centrum. Antologin i sin helhet är också ett fint exempel på just detta: läsaren får en god portion av den praktiska kunskap, fingertoppskänsla, tillit, lyhördhet, självreflexivitet och didaktiska kompentens som tycks krävas för att den normkritiskt inspirerade läraren 
ska kunna hantera de många, komplicerade och ofta snabba skeenden och processer som utspelas inom en utbildningsinstitution. En normkritisk pedagogik framstår på så sätt som en motvikt till den form av likabehandlingsarbete som främst lägger vikt vid barns och elevers individuella rättigheter, liksom korta punktinsatser som kan bockas av. Eller som Langmann (med referens till Moira von Wright) uttrycker det:

"[P]recis som all pedagogisk verksamhet handlar normkritiskt inspirerad pedagogik i slutändan om de stora och svårbesvarade frågorna - om människans grundläggande jämlikhet, om vad undervisning är och skulle kunna vara, om vad som framträder som pedagogiskt och etiskt ansvarsfullt, och inte minst, 'om hur det är att vara lärare och drömma om en bättre värld". (2019, I80)

Att vara lärare i en värld och inom ett skolsystem som är långt ifrån dem en önskar sig är inte det lättaste. Den normkritiska pedagogiken har som sagt sina rötter i den kritiska pedagogiken, med dess samhällsförändrande ambitioner. Men vilka möjligheter till samhällsförändring finns idag, när även politiken tycks underordnad ekonomin och när de flesta utbildningsinstitutioner styrs av nyliberala diskurser där individualism, effektivitet och mätbarhet är det som eftersträvas? Vivi Havia lyfter i sitt kapitel fram att normkritisk pedagogik ofta handlat om vuxnas bemötande av barn eller elever och om det som de möter i undervisningen. Men som hon poängterar behöver normkritiskt inspirerade pedagoger även rikta blicken mot de hierarkier de möter i förskolans eller skolans struktur och organisation. Martin Englunds kapitel sätter liknande typer av frågor i centrum: Vad innebär det att vara en normkritiskt inspirerad pedagog i ett rasifierat klassamhälle? Och vilka möjligheter att uppnå en inkluderande och jämlik skola finns det, när skolan befinner sig på en marknad och har som implicit mål att attrahera högpresterande och undvika lågpresterande elever? Som Englund skriver ska den normkritiska pedagogiken inte överskattas - den kan inte trolla bort strukturella problem. Att erkänna det är inte detsamma som att säga att den normkritiska pedagogiken saknar radikal potential. Snarare blir det 
möjligt att både utveckla de pedagogiska och didaktiska frågorna och att fråga sig vad mer som behövs för att större strukturella förändringar ska kunna äga rum, när det gäller både skolsystemet och samhället.

KLARA DOLK STOCKHOLMS UNIVERSITET

\section{REFERENSER}

Bromseth, Janne \& Darj, Frida (red.). 2oro. Normkritisk pedagogik: Makt, lärande och strategier för förändring. Uppsala: Centrum för genusvetenskap, Uppsala universitet. 